\title{
Correction to: Brief Montreal-Toulouse Language Assessment Battery: adaptation and content validity
}

\author{
Raira Fernanda Altmann ${ }^{1 *}$, Karin Zazo Ortiz ${ }^{2}$, Tainá Rossato Benfica ${ }^{1}$, Eduarda Pinheiro Oliveira ${ }^{1}$
} and Karina Carlesso Pagliarin ${ }^{1}$

\section{Correction to: Psicol Refl Crít 33, 18 (2020) \\ https://doi.org/10.1186/s41155-020-00157-6}

Following publication of the original article (Altmann et al., 2020), the authors identified an error in the author name of Eduarda Pinheiro Oliveira.

The incorrect author name is: Eduarda Pinheiro de Oliveira

The correct author name is: Eduarda Pinheiro Oliveira

The author group has been updated above.

\section{Author details}

'Department of Speech-Language Pathology, Universidade Federal de Santa Maria, Santa Maria/RS, Brazil. ${ }^{2}$ Department of Speech-Language Pathology, Universidade Federal de São Paulo, São Paulo, Brazil.

Published online: 30 September 2020

\section{Reference}

Altmann, R. F., et al. (2020). Brief Montreal-Toulouse Language Assessment Battery: adaptation and content validity. Psicol Refl Crit, 33, 18. https://doi.org/ 10.1186/s41155-020-00157-6.

\footnotetext{
The original article can be found online at https://doi.org/10.1186/s41155020-00157-6

* Correspondence: raira_altmann@hotmail.com

'Department of Speech-Language Pathology, Universidade Federal de Santa Maria, Santa Maria/RS, Brazil

Full list of author information is available at the end of the article
}

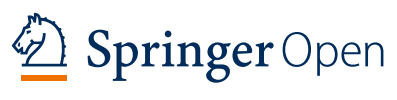

(c) The Author(s). 2020 Open Access This article is licensed under a Creative Commons Attribution 4.0 International License, which permits use, sharing, adaptation, distribution and reproduction in any medium or format, as long as you give appropriate credit to the original author(s) and the source, provide a link to the Creative Commons licence, and indicate if changes were made. The images or other third party material in this article are included in the article's Creative Commons licence, unless indicated otherwise in a credit line to the material. If material is not included in the article's Creative Commons licence and your intended use is not permitted by statutory regulation or exceeds the permitted use, you will need to obtain permission directly from the copyright holder. To view a copy of this licence, visit http://creativecommons.org/licenses/by/4.0/. 